\title{
REVISITING THE CORPORATE SOCIAL RESPONSIBILITY (CSR) AND PERFORMANCE RELATIONSHIP THROUGH A DYNAMIC RESOURCE MANAGEMENT VIEW
}

\author{
DOI: 10.17261/Pressacademia.2018.862 \\ PAP- V.7-2018(15)-p.97-100 \\ Rifat Kamasak ${ }^{1}$, Meltem Yavuz ${ }^{2}$ \\ ${ }^{1}$ Bahcesehir University, Istanbul, Turkey. \\ rifat.kamasak@eas.bau.edu.tr, ORCID: 0000-0001-8768-3569 \\ ${ }^{2}$ Istanbul University, Istanbul, Turkey. \\ meltem.yavuz@istanbul.edu.tr, ORCID: 0000-0002-8331-7999
}

To cite this document

Kamasak, R., Yavuz, M. (2018). Revisiting the corporate social responsibility (CSR) and performance relationship through a dynamic resource management view. PressAcademia Procedia (PAP), V.7, p.97-100.

Permemant link to this document: $\underline{\text { http://doi.org/10.17261/Pressacademia.2018.862 }}$

Copyright: Published by PressAcademia and limited licenced re-use rights only.

\begin{abstract}
Purpose- This paper aims to analyze the relationship between firms' corporate social responsibility (CSR) practices and economic performance. Additionally, this research explores the role of strategic flexibility (SF) which is the ability of a firm to adapt to changes in the external environment and make necessary organizational modifications quickly to direct its resources for a CSR activity, in this relationship. Methodology- The paper empirically investigates the CSR practices together with SF and their effects on firm performance with a study of 179 firms in Turkey using moderated multiple regression methods.

Findings- The results show that CSR practices are significantly associated with firm performance, indicating that a higher amount of CSR may improve financial performance.

Conclusion- Finally it was found SF plays a positive moderating role on the relationships between the CSR practices and firm performance. It is concluded that firms with higher skills of SF may obtain better economic performance from their CSR activities.
\end{abstract}

Keywords: Corporate social responsibility, strategic flexibility, firm performance, multiple regression, Turkish firms. JEL Codes: M10, M14, M19

\section{INTRODUCTION}

The relationship between corporate social responsibility (CSR) and financial performance has been examined by scholars for decades (Waddock \& Graves, 1997; Orlitzky, Schmidt, \& Rynes, 2003; Surroca, Tribo, \& Waddock, 2010; Zhao \& Murrell, 2016). The results of these studies provided evidence that firms' CSR practices were likely to lead to improved financial performance. According to a recent study of Mellahi et al. (2016), a majority of empirical studies in the field reports a positive association between CSR practices and firm performance. Therefore, a concensus among the scholars has come into existence on this relationship in the field. However, a closer look at the studies reveals a less clear issue that is the role of other mechanisms in this relationship (Liedong et al., 2015; Mellahi et al., 2016). This paper extends previous CSR practice-performance research from a static to a more dynamic view by exploring the moderating effects of strategic flexibility (SF) in the same study. The article suggests that implementation of an effective CSR strategy may be determined according to the firm-level resource availability. In the context of institutional theory and resource-dependency theory, a number of studies have explored the moderating role of government policy and regulations (Young \& Makhija, 2014) and the degree of institutional stability (Arya \& Zhang, 2009) on the relationship between CSR and firm performance. Yet, although the CSR practices of a firm are influenced by institutional forces, the capability of a firm to achieve the implementation of a successful CSR strategy may also be subject to firm-level resource availability and deployment (Helfat \& Peteraf, 2015; Sirmon et al., 2011). In this sense, the resource-based effects on the CSR practiceperformance relationship cannot be ignored (McWilliams, van Fleet, \& Cory, 2002; Mellahi et al., 2016). Most research to date has failed to satisfy the need for incorporating different perspectives in understanding CSR-performance relationship (Mellahi et al., 2016). Therefore, this study applies dynamic capabilities theory in tandem with resource-based theory to provide valuable insights on the CSR and strategic flexibility interaction and their performance effects.

\section{LITERATURE REVIEW AND HYPOTHESES}

Corporate social responsibility refers to "corporate actions that appear to advance some social good that allows a firm to enhance organizational performance, regardless of motive, corporate political activity deals with corporate attempts to manage political institutions and/or influence political actors in ways favorable to the firm" (Mellahi et al., 2016, p. 144). An extensive body of research finds that firms can benefit from a number of direct or indirect positive effects of CSR (Waddock \& Graves, 1997; Surroca et al., 2010; Zhao \& Murrell, 
2016). Surroca et al. (2010) examined the effects of a firm's intangible resources on firm success which was measured by CSR practices and financial performance with the use of a database comprising 599 companies from 28 countries. Results indicated that CSR practices stimulated the development of intangible resources such as innovation, human capital, reputation and organizational culture which led in turn to improved financial outcomes. Therefore, it is hypothesized that:

$H_{1}$ : CSR practices of a firm are significantly associated with the firm's financial performance.

In performing CSR practices, depending on the requirements of the business environment, firms may need to use their limited financial, human, relational, physical, and organizational resources in different combinations (Oliver \& Holzinger, 2008; Rehbein \& Schuler, 2015). Obviously, this situation necessitates a firm-level capability for the allocation and shift of different resources from one organizational repository to another in a quick and smooth manner (Nadkarni \& Herrmann, 2010). For example, while a firm was executing media campaigns and lobbying activities by using its financial and human resources to support some projects for public utility concerns, a sudden environmental change may result in a strong stakeholder demand or a new government regulation and may push the firm to enhance and diversify the content of its ongoing CSR program to create another philantrophic activity.

Strategic flexibility, which is defined as "a firm's ability to reconfigure resources, activities, and strategies quickly in response to environmental demands" (Brozovic, 2016, p. 5) deals with the flexible use of resources and reconfiguration of processes along with the offering of strategic variety and making quick decisions to take adequate actions to derive benefits from diversity in the environment. In this sense, as a dynamic resource management mechanism SF, which helps firms to perform strategic options that are subject to extensions of resource bases and/or creation of new resource bundles, has emerged as a crucial organizational requirement in order for actors to thrive in complex business environments (Brozovic, 2016; Zhou \& Wu, 2010). Given resource scarcity, where current resources of firms are strongly attached to the specified targets, SF, which is constituted by planning and decision making flexibility (Grewal \& Tansuhaj, 2001; Nadkarni \& Herrmann, 2010), resource flexibility and coordination flexibility (Wei, Yi, \& Guo, 2014; Zhou \& Wu, 2010) should moderate the relationship between the CSR practices and firm performance. Coupled with such flexible mechanisms, firms are more likely to purposefully create, extend or modify their resource-base to conduct successful CSR strategies that lead to superior firm performance in dynamic environments. Therefore, this study proposes that:

$\mathrm{H}_{2}$ : SF positively moderates the relationship between the CSR practices and firm performance.

\section{METHODS}

A self-administered questionnaire was used to collect data. The sample was selected from Istanbul Stock Exchange's BIST-100 Index that covers the firms from a broad scope of industries and different regions of Turkey. A total of 408 firms were approached and 179 useable questionnaires were obtained yielding a response rate of $43.8 \%$. The questionnaire consisted of a total number of 33 questions including 2 questions for demographics. The items of the questionnaire and their theoretical sources are described below. Responses to the items were recorded on a 5-point Likert-type scale and reliability and validity issues were assessed.

Corporate social responsibility (CSR): To measure corporate social activities, 12 items were taken from Turker's (2009) CSR measurement scale. Turker's scale was developed in Turkey based on the cultural context of the Turkish business environment and its reliability was tested and validated.

Strategic flexibility (SF): SF was measured by the combination of planning and decision making flexibility, and resource and coordination flexibility. In total, 10 items were used. Whilst 4 items for planning and decision making flexibility were taken from Grewal and Tansuhaj (2001), 6 items for resource and coordination flexibility were adopted from Wei et al. (2014) and Zhou and Wu (2010).

Performance: Firm performance was measured by 2 items: profitability and ROA. Respondents were asked to indicate their firms' performance compared to competitors for the previous three year period (2013-2015) in order to proximate a notion of sustained performance and to mitigate against temporal fluctuations.

Control variables: Firm age, firm size, risk, industry and environmental effects were controlled by 9 items in this study.

\section{ANALYSIS AND RESULTS}

Multiple regression analysis and the moderated method were used to test the above hypotheses. A four-step hierarchical analysis was conducted. The results of regression analyses are given in Table 1. 
Table 1: The Results of Regression Analyses

\begin{tabular}{|c|c|c|c|c|}
\hline \multirow[b]{2}{*}{ Variables } & \multicolumn{4}{|c|}{ ROA and Profitability } \\
\hline & Model 1 & Model 2 & Model 3 & Model 4 \\
\hline $\begin{array}{l}\text { 1. Firm age (log) } \\
\text { 2. Firm size (log) } \\
\text { 3. Risk } \\
\text { 4. Industry structure forces } \\
\text { 5. Environmental dynamism } \\
\text { 6. Corporate social responsibility (CSR) } \\
\text { 7. Strategic flexibility (SF) } \\
\text { 8. SF X CSR }\end{array}$ & $\begin{array}{l}0.143^{*} \\
0.121^{* *} \\
0.109^{*} \\
-0.102 \\
0.147^{* *}\end{array}$ & $\begin{array}{l}0.157^{* *} \\
0.104^{* * *} \\
0.128^{* *} \\
-0.096 \\
0.129^{* *} \\
0.376^{*}\end{array}$ & $\begin{array}{l}0.116^{* *} \\
0.121^{*} \\
0.094 \\
-0.075 \\
0.136^{*} \\
0.308^{* * *} \\
0.214^{* * *}\end{array}$ & $\begin{array}{l}0.093 \\
0.119 * * \\
0.112^{* *} \\
-0.073 \\
0.129 * * * \\
0.312 * * * \\
0.195^{* * *} \\
0.429 * *\end{array}$ \\
\hline Adjusted $R^{2}$ & 0.173 & 0.261 & 0.298 & 0.393 \\
\hline$\Delta R^{2}$ (adjusted) & - & 0.088 & 0.037 & 0.095 \\
\hline F-value & $3.254 * * *$ & $3.391 * * *$ & $3.412^{* * *}$ & $3.756 * * *$ \\
\hline
\end{tabular}

In model 1 , just the control variables, including firm age, firm size, risk, industry structure factors and environmental dynamism were entered and a significant share of the variance in firm performance (Adj. $R^{2}=0.173 ; F=3.254, p<0.001$ ) was observed. In model 2 and model 3, CSR and SF were added respectively and significant relationships between $\operatorname{CSR}(\beta=0.376, p<0.05)$ and $\operatorname{SF}(\beta=0.214, p<0.001)$ and firm performance were found. Therefore, $\mathrm{H}_{1}$ was supported. In model 4 , the moderating role of SF on the relationship between CSR and firm performance was assessed through entering the relevant interaction (SF X CSR).

The results found that the interaction of SF and CSR related positively to firm performance $(\beta=0.429, p<0.01)$. Besides, with a strong moderation effect of SF, the contribution of the two-way interaction of SF and CSR to explain the performance variation was the greatest, $9.5 \%\left(\Delta R^{2}=0.095 ; F=3.756, p<0.001\right)$. Thus, $H_{2}$ was also supported.

\section{DISCUSSION}

The findings relating to the first hypothesis indicate that firms that engage in CSR practices are likely to create better financial performance. In fact, this finding which once more shows the importance of a thorough CSR strategy of a firm is consistent with the findings of previous research in the field. The second hypothesis confirms that SF plays a positive moderating role on the relationships between the CSR practices and firm performance. The research finds that, as dynamic resource management capabilities, resource flexibility, coordination flexibility and planning flexibility as sources of SF can enable firms to create an optimum level of CSR activity, and the performance effects of CSR practices on firm performance is contingent on the level of SF. Therefore, resource portfolios can be extended, multifunctional resources can be accumulated, and resource bundles can be reconfigured (Sirmon et al., 2011) through resource aligning capabilities which are crucial to address the resource needs for CSR practices that lead firms to a better financial performance. Since the focus in this research moves from a static resource endowment view to a dynamic management view, the findings may also extend the current understanding of the resource scarcity assumption.

\section{REFERENCES}

Arya, B., Zhang, G. (2009). Institutional reforms and investor reactions to CSR announcements: evidence from an emerging economy. Journal of Management Studies, vol. 46, no. 7, p. 1089-1112.

Brozovic, D. (2016). Strategic flexibility: a review of the literature. International Journal of Management Reviews, DOI: $10.1111 /$ ijmr.12111.

Grewal, R., Tansuhaj, P. (2001). Building organizational capabilities for managing economic crisis: the role of market orientation and strategic flexibility. Journal of Marketing, vol. 65, no. 2, p. 67-80.

Helfat, C. A., Peteraf, M. A. (2015). Managerial cognitive capabilities and the micro-foundations of dynamic capabilities. Strategic Management Journal, vol. 36, no. 6, p. 831-850.

Liedong, T. A., Ghobadian, A., Rajwani, T., O’Regan, N. (2015). Toward a view of complementarity: trust and policy influence effects of corporate social responsibility and corporate political activity. Group \& Organization Management, vol. 40, no. 3, p. $405-427$.

McWilliams, A., van Fleet, D. D., Cory, K. D. (2002). Raising rivals' costs through political strategy: an extension of resource-based theory. Journal of Management Studies, vol. 39, no. 5, p. 707- 724. 
Mellahi, K., Frynas, J. G., Sun, P., Siegel, D. (2016). A Review of the non-market strategy literature: toward a multi-theoretical integration. Journal of Management, vol. 42, no. 1, p. 143-173.

Nadkarni, S., Herrmann, P. (2010). CEO personality, strategic flexibility, and firm performance: the case of the Indian business process outsourcing industry. Academy of Management Journal, vol. 53, no. 5, p. 1050-1073.

Oliver C., Holzinger, I. (2008). The effectiveness of strategic political management: a dynamic capabilities framework. Academy of Management Review, vol. 33, no. 2, p. 496-520.

Orlitzky, M., Schmidt, F. L., Rynes, S. L. (2003). Corporate social and financial performance: a meta-analysis. Organization Studies, vol. 24, no. 3, p. 403-441.

Rehbein, K., Schuler, D. A. (2015). Linking corporate community programs and political strategies: a resource-based view. Business \& Society, vol. 54, no. 6, p. 794-821.

Sirmon, D. G., Hitt, M. A., Ireland, R. D., Gilbert, B. A. (2011). Resource orchestration to create competitive advantage: breadth, depth, and life cycle effects. Journal of Management, vol. 37, no. 5, p. 1390-1412.

Surroca, J., Tribo, J. A., Waddock, S. (2010). Corporate responsibility and financial performance: the role of intangible resources. Strategic Management Journal, vol. 31, no. 5, p. 463-490.

Turker, D. (2009). Measuring corporate social responsibility: a scale development study. Journal of Business Ethics, vol. 85, no. 4, p. 411427.

Waddock, S. A., Graves, S. B. (1997). The corporate social performance-financial performance link. Strategic Management Journal, vol. 18 , no. 4, p. 303-319.

Wei, Z., Yi, Y., Guo, H. (2014). Organisational learning, ambidexterity, strategic flexibility, and new product development. Journal of Product Innovation Management, vol. 31, no. 4, p. 832-847.

Young, S. L., Makhija, M. V. (2014). Firms' corporate social responsibility behavior: an integration of institutional and profit maximization approaches. Journal of International Business Studies, vol. 45, no. 6, p. 670-698.

Zhao, X. P., Murrell, A. J. (2016). Revisiting the corporate social performance-financial performance link: a replication of Waddock and Graves. Strategic Management Journal, vol. 37, no. 11, p. 2378-2388.

Zhou, K. Z., Wu, F. (2010). Technological capability, strategic flexibility, and product innovation. Strategic Management Journal, vol. 31, no. 5, p. 547-561. 